\title{
PENSIONS REFORMS, WORKFORCE AGEING AND FIRM-PROVIDED WELFARE
}

\author{
Andrea Ricci \\ Giuliana Tesauro \\ Giuseppe Croce
}

11 
L'Istituto Nazionale per l'Analisi delle Politiche Pubbliche (INAPP) è un ente pubblico di ricerca che si occupa di analisi, monitoraggio e valutazione delle politiche del lavoro, delle politiche dell'istruzione e della formazione, delle politiche sociali e, in generale, di tutte le politiche economiche che hanno effetti sul mercato del lavoro.

Nato il $1^{\circ}$ dicembre 2016 a seguito della trasformazione dell'ISFOL e vigilato dal Ministero del Lavoro e delle politiche sociali, l'Ente ha un ruolo strategico - stabilito dal Decreto Legislativo 14 settembre 2015, n. 150 - nel nuovo sistema di governance delle politiche sociali e del lavoro del Paese.

INAPP fa parte del Sistema statistico nazionale (SISTAN) e collabora con le istituzioni europee. Da gennaio 2018 è Organismo Intermedio del PON Sistemi di Politiche Attive per l'Occupazione (SPAO) per svolgere attività di assistenza metodologica e scientifica per le azioni di sistema del Fondo sociale europeo ed è Agenzia nazionale del programma comunitario Erasmus+ per l'ambito istruzione e formazione professionale. $\dot{E}$ l'ente nazionale all'interno del consorzio europeo ERICESS che conduce l'indagine European Social Survey.

Presidente: Stefano Sacchi

Direttore generale: Paola Nicastro

\section{Riferimenti}

Corso d'Italia, 33

00198 Roma

Tel. +39.06.85447.1

web: www.inapp.org

Contatti: editoria@inapp.org

La collana Inapp Paper è a cura di Claudio Bensi.
La pubblicazione raccoglie i risultati di una ricerca curata dal Progetto strategico Inapp "Analisi strategica delle politiche pubbliche" (Responsabile Andrea Ricci).

Questo testo è stato sottoposto con esito favorevole al processo di peer review interna curato dal Comitato tecnico scientifico dell'Istituto.

\section{Autori}

Andrea Ricci, Giuliana Tesauro

Inapp

\section{Giuseppe Croce}

Department of Economics and Law, "La Sapienza" University of Rome

Testo chiuso: aprile 2018

Pubblicato: maggio 2018

\section{Coordinamento editoriale \\ Costanza Romano \\ Impaginazione ed editing grafico \\ Valentina Orienti}

Le opinioni espresse in questo lavoro impegnano la responsabilità degli autori e non necessariamente riflettono la posizione dell'ente.

Alcuni diritti riservati [2018] [INAPP]

Quest'opera è rilasciata sotto i termini della licenza Creative Commons Attribuzione - Non commerciale - Condividi allo stesso modo 4.0. Italia License.

(http://creativecommons.org/licenses/by-nc-sa/4.0/)

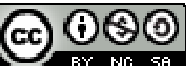

ISSN 2533-2996

ISBN 978-88-543-0171-9 


\section{ABSTRACT}

\section{Pensions Reforms, WORKForCe Ageing AND FIRM-PROVIDED Welfare}

In questo lavoro si analizza l'effetto esercitato da un innalzamento dell'età di pensionamento sulla propensione ad erogare/finanziare servizi di welfare aziendale. In particolare l'obiettivo dello studio è quello di verificare se e in che misura la riforma del sistema previdenziale influenza le politiche del personale all'interno delle aziende, soprattutto per ciò che concerne le coorti più anziane dei lavoratori. A tal fine si utilizzano i dati della Rilevazione su Imprese e Lavoro (RIL) condotta dall'Inapp nel 2015 e nel 2010 su un campione rappresentativo di imprese operanti nel settore privato extra-agricolo. L'applicazione di semplici modelli di regressione (lineari e non lineari) permette cosi di dimostrare come le imprese che, nel periodo 2013-2014, hanno rinunciato ad effettuare assunzioni già programmate a causa della Legge n. 214/2011 (cosiddetta Riforma Fornero) hanno sperimentato un incremento della probabilità di erogare servizi di welfare che può variare tra il $2,2 \%$ e il $10,5 \%$, in funzione delle diverse specificazioni econometriche. Tale risultato si conferma nel caso in cui si adotta un approccio controfattuale e, specificamente, tecniche di propensity score matching (PSM) tese a identificare nessi di causalità tra le variabili oggetto di studio. Infine, si discutono alcune implicazioni di politica economica

Parole chiave: invecchiamento, riforma previdenziale, welfare aziendale, propensity score matching.

\section{Pensions ReForMS, WORKForCe AGEING AND FIRM-PROVIDED WELFARE}

This paper investigates the impact of an exogenous increase in the legal retirement age on the firms' propensity to provide welfare services voluntarily to their employees. To this purpose we exploit a unique dataset derived from the Employers and Employees Survey, conducted by the National Institute for Public Policies Analysis (Inapp) in 2015 on a large and representative sample of Italian firms. By referring to the existing sociological and economic literature we make the hypothesis that a sudden increase in the share of older workers may motivate the employers to establish welfare schemes as a way to cope with an ageing workforce. The results obtained from different regression models show that firms which, as a consequence of the Law 214/2011 (the so-called "Fornero pension reform"), were forced to give up previously planned hirings increased the probability of providing welfare services at the workplace. This result also holds if propensity score matching methods are used in order to control for sample selection issues

Keywords: ageing, pension reform, firm-provided welfare, propensity score matching.

Per citare il Paper: Croce G., A. Ricci, G. Tesauro (2018), Pensions reforms, workforce ageing and firm-provided welfare, Roma, INAPP 


\section{INDICE}

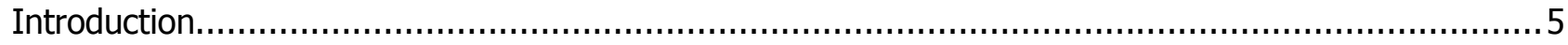

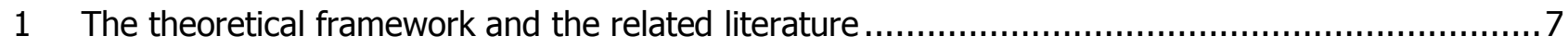

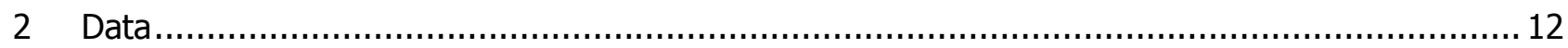

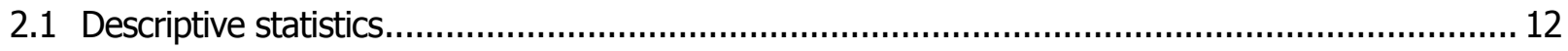

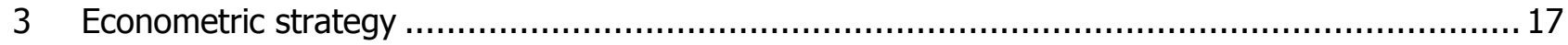

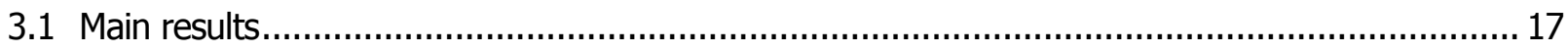

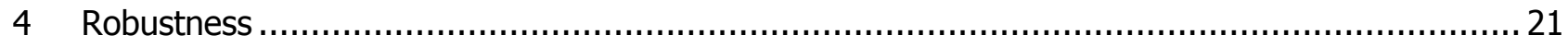

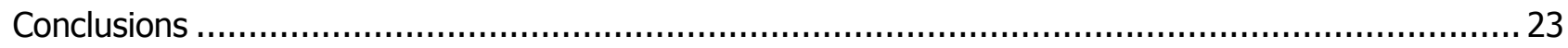

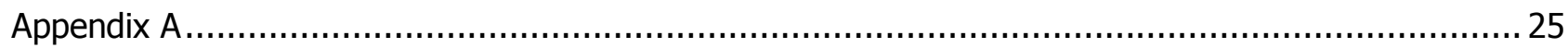

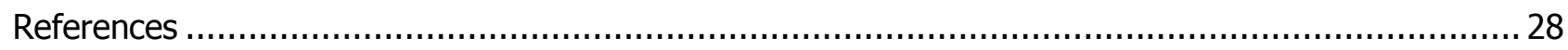




\section{INTRODUCTION}

Unlike the picture drawn by crudest economic models, employment has never consisted just in a simple exchange and this is especially true in present times. Indeed employment is becoming an increasingly complex relationship shaping the worker's wellbeing and productivity. Other than merely paying the worker a wage, the employer often invests on her/his workforce by providing training programs, measures to increase employability and welfare benefits and services. As the returns to these investments are expected to be positive they may represent a win-win option, with potential benefits to both parties.

The ageing population is a structural trend with major, possibly adverse, effects on the employment relationship. In most countries workers are forced to prolong their working life and postpone retirement, with a worsening of their life plans.

At the same time an extension in the retirement age may have an adverse effect on firms' profits because of the worsening of the wage-productivity balance. Such a negative impact is amplified in countries where employment protection legislation (EPL) prevents firms from dismissing older, less productive workers and at the same time wage rigidities make it difficult to apply wage cuts as a way to re-establish an equilibrium between labour cost and productivity.

However, a number of studies in the fields of sociology, human resource management and economics, suggests that both the wellbeing and productivity of old workers may be improved to some extent through employers' strategies.

This study investigates if and how firms react to a sudden pension reform. In particular we consider if a pension reform that implies an increase in the share of older employees in the firm's workforce, may spur employers to put in place firm-provided welfare schemes.

We define firm-provided welfare (FW) schemes as benefits that the firm provides on a voluntary basis to the employees in addition to the wage, following a unilateral decision or an agreement with unions, and whose cost are at least partially borne by the firm. This study considers whether FW has a role in a firms' strategy when dealing with an ageing workforce.

Recently, in Italy there has been a voluntarily distribution of benefits provided by firms. A wide variety of experiences in a large number of companies may be grouped under the heading 'FW' (Ascoli et al. 2012, Pavolini et al. 2013). A list of the benefits and services offered to the employees includes private pension plans, financial support schemes, parental leaves and childcare services, health care assistance, training, household expenses allowances, measures for long term care.

While the largest part of the literature is concerned with the labour supply effects of pension reforms, we follow a more recent line of research concerned with the demand-side effects and consider the adjustments made by firms to react to a sudden increase in the retirement age established by the law and, more broadly, to deal with an ageing workforce. As noted by Vandenberghe (2013), an increase in employment rates of the elderly may only happen if firms are actually willing to employ them. The Economist wrote recently that while "governments are raising retirement ages and making it more difficult for companies to shed older workers, in a desperate attempt to cope with their underfunded pension system, (...) companies 
will have no choice but to face the difficult problem of managing older workers" (The Economist 2010). Then, any attempt at postponing the retirement age can be effective to the extent that employability and productivity of older workers are actually preserved and fostered (Skirbekk 2008).

However, the economic literature focusing on the demand side of ageing has mostly considered so far how it affects productivity and labour costs with little attention to the effects of the reforms on the firm reactions. Moreover, the few studies concerned with these effects have limited themselves to the short-term impact on hirings and labour turnover.

This paper substantially adds to this line of research as we extend the scope of it by investigating whether the provision of welfare benefits represents a strategy chosen by the employers to cope with the effects of an unexpected pension reform. We make the hypothesis that, beyond the immediate freeze of hirings, firms hit by the effect of the reform are more likely to adopt a voluntary provision of welfare benefits.

Despite their rapid growth, there are still rare empirical analyses on the FW schemes. To this regard this paper contributes to shed some light on the major factors, namely firms' workforce characteristics, leading the employers to bear their costs. The findings obtained may offer useful insights in order to draw firms and government strategies to deal effectively with the forthcoming ageing workforce.

We utilize a unique dataset from a large and representative survey on Italian firms (the EES survey carried out by Inapp), which allows to detect firms whose hiring plans have been affected by the reform and test whether, as a consequence of that, these firms are more likely to adopt FW schemes. This kind of analysis represents an absolute novelty and is an important step forward in this literature since, to the best of our knowledge, no other study has so far considered an employers' response to a pension reform.

Our results show that FW schemes are offered by $4.3 \%$ of the firms but this percentage reaches $24 \%$ among the larger firms. The econometric estimates through OLS and probit models point out a strong association between the pension reform and the provision of FW. Finally, by a propensity score matching approach we run a counterfactual analysis which proves that the sudden increase of the retirement age brought about by the pension reform increases the likelihood of FW schemes.

The section that follows summarizes briefly the relevant literature on the implications of the pension reform and, more broadly, the effects of an ageing workforce on firms' behaviour. At the end of this section the hypotheses tested in the empirical analysis are formulated. Section 3 presents our sample and descriptive statistics. The fourth section displays and comments the results obtained through OLS and Probit estimates. The fifth section presents the findings of the propensity score matching estimate in order to prove the robustness of our main result. The last section concludes. 


\section{THE THEORETICAL FRAMEWORK AND THE RELATED LITERATURE}

The pension reform has forced older employees who were about to retire under previous rules to postpone their retirement. This may have major implications not only for the workers but also for the firms (see Vandenberghe 2013 for a review of the literature on the effects of ageing and retirement rules on the labour demand side). The most likely short-term reaction by the firms to a sudden increase of the retirement age is giving up hiring plans.

Boeri et al. (2016) report a clear evidence of a negative impact of the same pension reform on hirings. According to their results hirings are reduced by one unit for each five workers who were forced to stay in the firm under the new retirement rules instead of retiring. In another paper looking at the effects of this reform on the employers' choices, Bovini and Paradisi (2017) find an increase in the separation rate, a decrease in the renewal of temporary contracts, and a lower likelihood that temporary contracts are converted into permanent employment. Most importantly, the number of new hirings is reduced. Similarly, Martin et al. (2009) show that the increase in the retirement age of females in Portugal caused a reduction of young women hirings.

Beyond these short-term reactions, following the sudden increase in the share of older workers, the employers may be forced to find a way to avoid long-term profits loss. From a theoretical point view, the firm's profits are adversely affected by an increase in the retirement age only if the wage of the elderly is above their productivity. In a less than perfectly competitive labour market, where wages do not adjust instantaneously to productivity, an increase in the retirement age is likely to worsen the firms' balance sheet. In particular, this is the case when older workers' productivity stops rising or even decreases after a certain age while wages keep increasing with age, as predicted by the delayed payment model (Lazear 1979, 1990). As a consequence the productivity of older workers lies below their wage and the extension of the working age causes a profits loss (van Dalen et al. 2010).

As it happens, the empirical relationship between age and productivity still remains a controversial issue as highlighted by reviews of existing studies (Skirbekk 2008, Vandenberghe 2013, Van Ours and Stoeldraijer 2010). The possible decline of older workers productivity may follow the obsolescence of their human capital or the weakening of their mental and physical conditions (Barth et al. 1993), which may imply higher absenteeism and lower workload (Boeri et al. 2016). Results showing a productivity decline with age are reported for different countries by Grund and Westergard-Nielsen (2008), Aubert and Crépon (2007), and Lallemand and Rycx (2009). Van Ours and Stoeldraijer (2010) find some evidence on Dutch data of a pay-productivity gap for higher age. Similar results are shown by Hellerstein and Neumark (2004), Dostie (2006) and Ilmakunnas and Maliranta (2007). Vandenberghe (2013) estimates that an increase in the share of older women causes a fall of productivity and gross profits. The author argues that health issues and informal caring may drive less attachment to the labour force and lower productivity of females.

On the contrary, the findings of Mahlberg et al. (2013) do not show neither an impact of the share of older employees on firm productivity nor any evidence for the overpayment of older workers. 
However, Van Ours and Stoeldraijer (2010), after reviewing the literature on the relationship between age, wage and productivity, conclude that, although not unanimously, most studies find that productivity doesn't increase with age as much as wages do.

Accordingly, the employers have to manage the reduction in the productivity-wage gap. To this end they may act on the costs by cutting the wages of older workers, or by demoting or dismissing them (Martin et al. 2009, D’Addio et al. 2010, Clark and Sandler Morrill 2017).

Alternatively, they may opt for more proactive responses aimed at sustaining their productivity by maintaining their human capital and health, promoting flexibility, and strengthening their motivation (Bloom et al. 2010, European commission 2012).

The wage cut may be unfeasible due to rigidities, e.g. in the case of collective bargaining, and may be highly controversial as it would represent a renege of the firm commitment with adverse consequences on the reputation of the employer. The same reasoning applies to the demotion of older workers. At the same time, the dismissal of older workers may be difficult as a consequence of the employment protection legislation regime and of union resistance.

Rather than cutting older workers' wages or dismissing them, an employer might opt for strategies aiming at contrasting the decline of their productivity. To this end, training can be adopted to maintain and upgrade workers' skills and various health measures can be introduced to prevent occupational diseases and to face health deterioration (Skirbekk 2008, Bloom and Sousa-Poza 2013). Moreover, internal flexibility may allow more suitable working time arrangements and tasks assignments in order to cope with the demands of an ageing workforce (Barnes et al. 2009; Bloom et al. 2010, van Dalen et al. 2010, Atkinson and Sandiford 2016). Also the adaptation of technologies and ameliorations of ergonomics at the workplace may support the productivity of aged employees and increase internal flexibility. Recent research provides evidence that management's interest in workers' well-being may be effective in reducing absenteeism (Othman et al. 2015).

The results found by Göbel and Zwick (2013) are especially important for our argument as they show that specific measures of policy personnel adopted by the firm are effective in increasing the relative productivity of aged employees. Namely, in their findings retraining and working time reductions specifically targeted to old workers are found to be ineffective. Conversely, other measures like equipment changes to avoid hearing and vision problems, improvements in the work environment and the redefinition of job assignments, do actually improve their productivity. This evidence supports the view that firms may react to an exogenous increase in the retirement age not only through measures aimed at saving labour costs but also implementing actions with the purpose of improving the productivity of older employees. In addition, Göbel and Zwick (2013) document that human resources measures targeted to old employees are not a marginal phenomenon. According to their data, $28 \%$ of German establishments employing old workers have resorted to at least one of them.

The productivity and labour force participation of the elderly depend largely on the resources devoted to their preventive health (Aisa et al. 2015). Not only physical but also mental health represents a keyissue in order to insure participation and productivity of older workers considering that mental difficulties are the most important cause of disability benefits claims in a number of European countries 
(European Commission 2012). The problem of conciliation of work and family duties sharpens when adult children have to care for their elderly parents (Niimi 2017). Thus, allowing time flexibility and some financial support for care services may help to reduce absenteeism and early retirement.

Furthermore, the productivity decline may also follow from insufficient incentives. The lack of motivation may get worse due to an unexpected pension reform which impedes personal life plans and deteriorates job satisfaction.

From this point of view, a wage cut hardly represents a remedy for the firm as it could harm workers' morale and depress their effort as revealed in field experiments (Howitt, 2002; Kube et al., 2013). On the contrary, the provision of non-mandatory benefits may contribute to restore the worker's motivation. Fairness consideration may offer a rationale to better approach workforce ageing through human resource management practices which rely on the role of non financial rewards offered to the workers (Parry, 2008, Tishman et al., 2012).

Despite the idea that the adoption of performance-based pay systems might be a way of promoting the productivity of older workers and restoring firms profitability, this option has several drawbacks and the seniority-based systems are likely to retain the standard pay system. Experimental evidence and theoretical reasons suggest that pay for performance schemes may be ineffective if the parties value fairness and reciprocity. In this case employers may take advantage from treating their workers with generosity as preference for fairness will motivate them to reciprocate (Fehr et al. 2009). Moreover, non monetary gifts may have even stronger effects on workers' performance than cash gifts of equivalent money value (Kube et al. 2011).

On the basis of the insights derived from the existing literature discussed so far, we make our first, main hypothesis:

Hypothesis 1: after a sudden pension reform increasing the retirement age, the employers who suffered from the unexpected increase in the share of older employees are more likely to provide welfare benefits.

In our understanding the FW represents a multifaceted and adaptable bundle of benefits and services which may be effective to promote old workers' wellbeing as well as to sustain their productivity. Such effects on productivity may explain the positive attitude of the employers towards the provision of benefits and services.

In particular, two effects on productivity can be distinguished. First, in line with the background literature, the benefits may directly help to increase the productivity of the older employees. As they suffer from a reduction of their human capital, due to skills obsolescence or to the weakening of physical and mental capacity, specific measures and benefits may be designed to cope with their needs. Firms' welfare may provide training, conciliation arrangements, working time flexibility, health services and therapies, medical insurance aimed at preventing the worsening of the productivity decline and avoiding typical adverse effects like increase in absenteeism. 
Second, benefits may help to restore a higher level of job satisfaction and countermeasure the lack of incentives. The pension reform represents for the worker a breach of the employment contract which initially established an earlier retirement date. Moreover, it implies a deadweight loss as it extends the working life with no effect on the amount given for retirement. The provision of well being-enhancing benefits may give the employees who suffered this loss a compensation and restore the sense of fairness on the job. This may motivate them and avoid a decline in their effort (Tachibanaki 2003). The beneficial effects of the employer-provided benefits on productivity are larger, the more suitable they are for the older workers' demands and preferences.

Besides this main hypothesis, we formulate two other supplementary hypotheses on possible major determinants of the welfare provision by the employers. We consider them as supplementary since they focus on factors that in principle may be independent from the pension reform, which is the focus of this paper. However, they allow a better understanding of the possible relationships between firm' characteristics and the choice of providing benefits and services. Moreover, they may convey further firm-level interactions resulting in welfare provision.

Hypothesis 2: 2.1) those with a larger share of highly educated employees, 2.2) those with a larger share of employees who participated in training, and 2.3) those engaged in some kind of innovation activities, are more likely to provide welfare benefits.

If the employers consider the human capital of their employees as a strategic asset they need to avoid voluntary resignations of more skilled workers. In particular the employers might be concerned about the loss of the most educated and, maybe also of the older workers as they are more experienced. The FW may be helpful for the employers in keeping such workers. The fear of the poaching of skilled workers is even stronger for the firms which invest more intensively in workplace training activities. From this point of view training and welfare provision benefits may be seen as complements. By providing non-transferable benefits the employer is able to hamper resignations to the purpose of saving its investments in transferable training. Furthermore, welfare provision may enable the firm to motivate and compensate the workers' involvement in innovation strategies.

The other supplementary hypothesis concerns the possible role of the union. In our opinion this important institutional feature which shapes the employment relationships in the firm may interact also with the firm's decision to provide welfare.

Hypothesis 3: the firms where union representatives are present, are also more likely to offer welfare benefits.

Even though the provision of welfare is presumed to be decided unilaterally by the employer, often it comes from collective agreements. As the unions consider such provision as a way to redistribute the company surplus, we expect that the presence of a union in the firm is 
positively associated with the FW. It seems also reasonable that after a major pension reform which postpones the retirement date, unions claim welfare benefits from the employer as a form of compensation for the welfare loss suffered by their older members. Indeed, the unions represent especially the interests of more aged, insider workers. On the other hand, the employers are willing to accommodate this claim since productivity-enhancing benefits allow a win-win exchange. 


\section{Data}

The empirical analysis is based on data derived from the Employers and Employees Survey (EES) conducted by the National Institute for the Analysis of Public Policies (Inapp) in 2015 on a representative sample of over 29,000 partnerships and limited liability firms operating in the nonagricultural private sector ${ }^{1}$.

The EES survey collects a unique set of information about employment composition, personnel organization, industrial relations and other firms' characteristics. In particular, the EES questionnaire provides data about the incidence and components of the welfare services (health insurance, pension plans, fringe benefits, family allowances/aids, maternal leaves and child care, etc.) provided or financed by firms to their employees; in addition we have detailed information about the workforce composition, firms' characteristics, corporate governance and industrial relations.

The empirical analysis is run on a large sub-sample of EES, obtained by excluding only firms with less than 9 employees. This sample selection guarantees to retain only those firms characterized by a minimum level of internal organization and structured personnel policies.

\subsection{Descriptive statistics}

Table 1 displays the summary statistics about the incidence and composition of the firm-provide welfare provision. On average, $4.3 \%$ of firms provide at least one kind of welfare services to their employees. According to the EES questionnaire this figure includes the provision of services decided unilaterally by the employers as well as those bargained with the unions at the firm level or delivered through the so called enti bilaterali (institutions managed by the social partners on a local and sectoral basis to collect funds and provide welfare benefits to the employees).

Table 1 also reports the average share (and the standard deviation) of each component of the FW as a fraction of firms delivering it on the total number of firms included in the EES sample. The largest share, equal to $1.6 \%$, is that of the residual component which includes fringe benefits, payments towards real goods and so forth. The second largest share is represented by firms offering healthcare allowances $(1.2 \%)$, while the third one refers to employers who provide maternity leaves and childcare services $(0.8 \%)$. The provision of private pension plans regards $0.6 \%$ of the sample while aids to current family expenditures amounts only to $0.2 \%$ of it.

According to these figures the provision of welfare by the employer is far from being concentrated on a specific measure or in a particular field. On the contrary, it encompasses a wide variety of services and benefits, suggesting that the employers adapt this instrument to a large range of needs and circumstances. Such adaptability represents a salient feature of the welfare programs established by the companies. As argued also by Davis and Kalleberg (2006), the employers may resort to the welfare provision to cope with a number of different demands.

\footnotetext{
${ }^{1}$ In italian, Rilevazione su Imprese e Lavoro (RIL). For more details see: http://www.inapp.org/it/ril
} 
Table 1 - Descriptive statistics: incidence and type of welfare services

\begin{tabular}{|c|c|c|c|c|c|}
\hline Welfare services provided by firms & $\mathrm{N}$ of obs & Media & Std Dev & Min & Max \\
\hline Total & 14,600 & 0.043 & 0.204 & 0 & 1 \\
\hline Maternity leaves and child care & 14,600 & 0.008 & 0.091 & 0 & 1 \\
\hline Family allowances/aids (education, expenditures, ecc) & 14,600 & 0.002 & 0.045 & 0 & 1 \\
\hline Health care & 14,600 & 0.012 & 0.107 & 0 & 1 \\
\hline Private pension plans & 14,600 & 0.006 & 0.075 & 0 & 1 \\
\hline Other (fringe benefits, ecc) & 14,600 & 0.016 & 0.124 & 0 & 1 \\
\hline
\end{tabular}

Source: EES 2015. Note: sampling weights applied

Overall Table 1 indicates that, as noted by Ferrera and Maino (2014), private welfare provision in Italy still has a limited diffusion. However, it is worth noticing that its incidence increases markedly if we consider that, as the firms providing welfare are mostly large firms, the share of workers involved as potential recipients of the benefits and services provided by their employers is much more sizeable, equal to $19.1 \%$, which corresponds to almost 1 million and 450 thousands employees (see Table A1). As expected, the diffusion of the FW schemes is heavily affected by firms' size, geographical localization and sector of activity. As shown by Table 2 their incidence increases from 3\% among firms with a number of employees between 10 and 50 , to $23.7 \%$ among those with more than 250 employees. Therefore, the likelihood of receiving welfare benefits from large firms is about eight times that of small firms.

As for macro-regions, welfare services are more frequent in the North Western (5.8\%) and North Eastern (4.9\%) regions, whereas they are much rarer in the Southern ones (1.7\%). In addition to this, we find significant differences across sector activities. Namely, the probability of welfare provision is highest in the production and distribution of energy, gas and water supply (15.7\%), lower in ICT, finance, insurance services $(9,7 \%)$ and business services $(6,1 \%)$, and even lower in the construction industry $(2.4 \%)$, tourism, trade sectors $(2.7 \%)$ and transportation $(3.0 \%)$. These figures confirm previous evidence provided by Pavolini et al. (2013). 
Table 2 - Incidence and type of social services by size, macro-area and sector

\begin{tabular}{|c|c|c|c|c|c|c|}
\hline & & & & of welfa & services & \\
\hline & $\begin{array}{c}\text { Total } \\
\text { incidence }\end{array}$ & $\begin{array}{l}\text { Maternity } \\
\text { benefits }\end{array}$ & $\begin{array}{c}\text { Family } \\
\text { expenditures }\end{array}$ & $\begin{array}{l}\text { Health } \\
\text { care }\end{array}$ & $\begin{array}{l}\text { Pension } \\
\text { plans }\end{array}$ & $\begin{array}{c}\text { Other } \\
\text { (fringe benefits, ecc) }\end{array}$ \\
\hline Firm size & & & & & & \\
\hline $9<$ n. of employees $<50$ & 3.0 & 22.0 & 3.4 & 23.8 & 13.3 & 37.5 \\
\hline $49<$ n. of employees $<250$ & 11.7 & 10.2 & 4.8 & 30.1 & 14.1 & 40.8 \\
\hline $\mathrm{N}$ of employees $>249$ & 23.7 & 30.1 & 12.4 & 34.8 & 9.9 & 12.8 \\
\hline Macro-region & & & & & & \\
\hline North West & 5.8 & 13.1 & 4.8 & 38.1 & 15.7 & 28.4 \\
\hline North East & 4.9 & 15.8 & 3.8 & 16.2 & 12.4 & 51.8 \\
\hline Centre & 3.6 & 27.8 & 6 & 25.9 & 11.5 & 28.8 \\
\hline South & 1.7 & 49.2 & 5.3 & 8.4 & 5.7 & 31.3 \\
\hline Sector of activity & & & & & & \\
\hline Energy, gas water, ecc & 15.7 & 5.1 & 0.5 & 82.1 & 4.9 & 7.4 \\
\hline Food, textile, tobacco & 4.1 & 29.9 & 2.9 & 28.4 & 4.3 & 34.4 \\
\hline Chemstry e metallurgia & 4.8 & 12.6 & 6 & 18 & 21.7 & 41.8 \\
\hline Meccanica e altra manifattura & 4.7 & 11.4 & 5.5 & 34 & 22.6 & 26.6 \\
\hline Buildings & 2.4 & 8.9 & 3.9 & 20.8 & 29.1 & 37.3 \\
\hline Trade, tourism, hotels, ecc & 2.7 & 30.7 & 4.5 & 18.2 & 10.4 & 36.2 \\
\hline Trasportation & 3.0 & 27.2 & 6.9 & 26.1 & 18 & 21.7 \\
\hline$I C T$, finance, insurance services & 9.7 & 16.8 & 10.3 & 29.2 & 14.4 & 29.3 \\
\hline Business services & 6.1 & 8.3 & 2.7 & 20.7 & 5.7 & 62.6 \\
\hline $\begin{array}{l}\text { Private social services, education, } \\
\text { health ecc }\end{array}$ & 3.7 & 69.6 & 4.8 & 6.3 & 10.9 & 8.4 \\
\hline Total & 4.3 & 19.1 & 4.7 & 26.9 & 13.2 & 36.2 \\
\hline
\end{tabular}

Source: EES 2015. Note: sampling weights applied; * percent values

The higher incidence of FW in public utilities and in finance may be explained by the low competition that often prevails on the output markets of such industries. In this case the provision of welfare may represent a tool to redistribute monopolistic rents from the firms to the employees (Tachibanaki 2003). On the contrary, in industries that are more exposed to competition, like manufacturing, the provision of benefits by the employer is more often finalised to increase productivity by attracting, motivating and retaining employees, especially the more qualified and highly educated ones.

To better understand which are the main factors driving or impeding the diffusion of welfare services at the workplace in Italy, the institutional and economic characteristics of its productive system must be considered. To this purpose Table 3, which shows weighted descriptive statistics for the main variables used in the empirical analysis, offers useful insights.

First of all we observe that on average $6 \%$ of the firms cut down their hiring plans over the period 2013-2014 as a consequence of the pension reform (214/2011) (see Quaranta and Ricci, 2018). As for the characteristics of the management and of the corporate governance, we find that only $26.5 \%$ of the firms in the sample are run by managers with tertiary education, while $53.4 \%$ of them are run by managers with upper secondary education and the remaining $20.2 \%$ by managers with lower secondary or primary education. Such employers' educational profiles combines with the predominance of small (below 50 employees) and family firms, which amount to $86.7 \%$ and $85.2 \%$, respectively, whose management typically requires less formal education than large and market-owned companies. 
It is worth noting that private provision of social services may also be introduced by means of second level agreements with the unions. However Table 3 indicates that only in less than one out of five firms $(19.7 \%)$ there is a union. This fact too contributes to the limited and uneven diffusion of the provision of welfare by the employers. Concerning the workforce structure, the share of employees with a tertiary education degree is $10.6 \%$ while the shares of those with upper secondary or lower secondary education are $46.2 \%$ and $43.3 \%$, respectively. The low education attainment of the workforce depends also on the weaker demand for qualified workers in Italy already highlighted in previous studies (Naticchioni et al. 2010). Furthermore, only $35.6 \%$ of all employees have received some training, in line with the complementarity between training investment and schooling in the workplace (Bassanini et al, 2005), while the workers with a fixed-term contract represented $12 \%$ of the total workforce in 2010 .

Our dataset also provides information on a set of firm characteristics such as investment in innovations, economic performance and production specialization. The majority of the firms are not involved in innovation strategies: only $36.6 \%$ and $33.2 \%$ of them have undertaken product or process innovation, respectively, in the three years preceding the survey. Finally, more than $61 \%$ of them are located in the Northern regions.

Table 3 - descriptive statistics of the EES sample

\begin{tabular}{|c|c|c|c|c|c|}
\hline & $\mathrm{N}$ of obs & Media & Std Dev & Min & Max \\
\hline Pension reform 214/2011 & 14,600 & 0.060 & 0.238 & 0 & 1 \\
\hline \multicolumn{6}{|l|}{ Workforce characteristics } \\
\hline$\%$ aged $>49$ & 14,600 & 0.231 & 0.193 & 0 & 1 \\
\hline$\% 34<$ aged<50 & 14,600 & 0.488 & 0.213 & 0 & 1 \\
\hline$\%$ aged less than 35 & 14,600 & 0.281 & 0.224 & 0 & 1 \\
\hline$\%$ graduated & 14,600 & 0.106 & 0.184 & 0 & 1 \\
\hline$\%$ upper secondary & 14,600 & 0.462 & 0.279 & 0 & 1 \\
\hline \% lower secondary & 14,600 & 0.433 & 0.316 & 0 & 1 \\
\hline$\%$ fixed term contract & 14,600 & 0.120 & 0.209 & 0 & 1 \\
\hline$\%$ female & 14,600 & 0.332 & 0.265 & 0 & 1 \\
\hline$\%$ trained & 14,600 & 0.356 & 0.409 & 0 & 1 \\
\hline Union & 14,600 & 0.197 & 0.397 & 0 & 1 \\
\hline \multicolumn{6}{|c|}{ Management and governance } \\
\hline Graduated & 14,598 & 0.265 & 0.441 & 0 & 1 \\
\hline Upper secondary & 14,598 & 0.534 & 0.499 & 0 & 1 \\
\hline Lower secondary & 14,598 & 0.202 & 0.401 & 0 & 1 \\
\hline Family firm & 14,530 & 0.852 & 0.355 & 0 & 1 \\
\hline \multicolumn{6}{|l|}{ Firms characteristics } \\
\hline Product innovation & 14,600 & 0.366 & 0.482 & 0 & 1 \\
\hline Process innovation & 14,600 & 0.332 & 0.471 & 0 & 1 \\
\hline In (sales per employee) & 12,436 & 14.827 & 1.614 & 0 & 26.0 \\
\hline $9<\mathrm{n}$ of employee $<50$ & 14,600 & 0.867 & 0.340 & 0 & 1 \\
\hline $49<\mathrm{n}$ of employee $<250$ & 14,600 & 0.116 & 0.320 & 0 & 1 \\
\hline N of employee $>249$ & 14,600 & 0.018 & 0.131 & 0 & 1 \\
\hline North Ovest & 14,600 & 0.331 & 0.471 & 0 & 1 \\
\hline North East & 14,600 & 0.284 & 0.451 & 0 & 1 \\
\hline Centre & 14,600 & 0.191 & 0.393 & 0 & 1 \\
\hline South & 14,600 & 0.193 & 0.395 & 0 & 1 \\
\hline
\end{tabular}

Source: EES 2015. Note: sampling weights applied 
Beyond these descriptive statistics, in the next section we verify if the workplace and the firm's characteristics influence the provision of welfare services focusing especially on the role of the recent pension reform. 


\section{ECONOMETRIC STRATEGY}

To analyze the impact of pension reforms on the probability that firms decide to provide welfare services to their employees, we estimate the following equation:

$$
\text { Welfi }=\alpha \cdot \text { Pens }_{i}+\beta \cdot M_{\mathrm{i}}+\delta \cdot W_{\mathrm{i}}+\gamma \cdot F_{\mathrm{i}}+\varepsilon_{\mathrm{i}}
$$

where Welf $_{i}$ as a dummy variable indicates the occurrence of private welfare at firm $i$, and Pens $s_{i}$ is our key explanatory variable which points out whether hiring plans were cut down because of the mandatory increase in the retirement age established by the reform occurred in December 2011. As for the other control variables, vector $M_{i}$ includes management and corporate governance characteristics, while $W_{i}$ represents the workforce composition and $F_{i}$ describes the firms' productive specialization and other workplace characteristics (see Appendix Table A for details). Finally, $\varepsilon_{i}$ is an idiosyncratic error term.

To test the hypothesis discussed in section 2, equation (1) is estimated by performing both linear probability and Probit regression models to account for the dichotomous nature of the dependent variable (Wooldridge, 2010).

However, potential concerns with this empirical strategy regard the firms' heterogeneity and endogeneity issues. In particular, if some factors that influence both hiring plans and the provision of welfare services are not taken into account, OLS and Probit estimates may suffer from omitted variable biases. Further, while it is reasonable to argue that the pension reform was an exogenous and unanticipated shock, we cannot assume that firms that cut down their hiring plans are statistically identical to those that had not planned to hire over the period 2012-2014 2 .

As a consequence, a positive estimated coefficient for the variable Pens $s_{i}$ might reflect, for example, the adoption of high-quality human resource management practices or the features of the corporate governance rather than a short term causal impact of the pension reform. We deal with these issues in the rest of the chapter. First we include in the right hand side of equation (1) a large set of control variables aimed at capturing important dimensions of firms and workforce heterogeneity. Second, we perform propensity-score matching estimates as a robustness check to cope with the potential selection bias in the treatment

\subsection{Main results}

Table 4 reports the regression results obtained for three different specifications of equation (1): a baseline specification where Pens $s_{i}$ is the only explanatory variable (columns [1] and [4]); a second specification including controls for the workforce composition and industrial relations, as formalized by the presence of the union at the workplace (columns [2] and [5]); and a third, full specification that

\footnotetext{
${ }^{2}$ As discussed in previous studies (Boeri, Garibaldi, Moen, 2016) the policy change known as Monti-Fornero reforms generated a sudden and unexpected increase in the contributory and age requirements for retirement, forcing firms to keep workers previously entitled to a pension to stay in the payroll, affecting the hiring plans (labor demand). [In our sample-data] the share of workers hit by the policy change in the retirement rules are those in the 50-64 age groups.
} 
takes into account also a set of explanatory variables for firm characteristics and economic performance (columns [3] and [6]).

First, let us consider the OLS coefficient estimates reported in columns [1]-[3]. Here, all estimates indicate that the provision of welfare services by the employer is positively related to renouncing new hires because of the pension reform. In particular, giving up hiring plans is associated to an increase in the probability of providing welfare services by $7 \%$ in the baseline specification (column [1]), to $5 \%$ when the workforce composition and the union presence are controlled for (column [2]) and to $2.9 \%$ in the full regression, where also firm characteristics and productive specialization are added as explanatory variables (column [3]). This result, which remains statistically highly significant even after the inclusion of a wide set of controls, offers a first support to our main hypothesis (hypothesis 1) that events causing a sudden ageing of the workforce, like the tightening of the requirements for retirement, increases the likelihood that the firm offers welfare benefits.

Looking at the estimated results for the specification, including the workforce and firm characteristics, gives us a better picture of the factors affecting this choice. First of all, from the estimates reported in column [2] we see that neither the share of older workers (between 50 and 65) nor that of middle age workers (between 34 and 50) is significantly correlated to social benefits. On the one hand, this finding contradicts our expectation, as it seems reasonable to believe that firms with an older workforce face a greater demand for benefits and services. On the other hand, if the recipients are older the expected return to the investment in these measures is lower as the pay-off period is shorter and the costs may be higher (Fleischmann et al. 2015). Moreover, in our reasoning it is not the share of aged employees per se which is relevant but the sudden and unexpected increase of it after the pension reform (as measured by variable $P e n s_{i}$ ).

According to the hypotheses 2.1 and 2.2, the composition of the workforce by skill level is expected to be a more powerful determinant of welfare provision. Indeed estimates show that the employer propensity to provide welfare services increases with the percentage of workers holding a tertiary degree. This suggests that firms which value the most the qualified labour may offer some benefits in addition to the wage with the intention of attracting and retaining highly educated workers (Barnes et al. 2009).

For the same reason the probability of welfare provision is found to be higher in firms where there is a higher percentage of trained workers. As argued in the theoretical section, the firms willing to offer training to their employees are also interested in giving them welfare benefits in order to defend their investment and to prevent poaching. Also Davis and Kalleberg (2006), Pavolini et al. (2013) and Fleischmann et al. (2015) highlight that welfare benefits may act as a managerial instrument to avoid the loss of employees through voluntary dismissal.

On the contrary, quite surprisingly gender composition does not exert any influence on the choice of providing welfare (except that in the full model reported in column [3], where its coefficient is positive and statistically significant), even though it could be expected that a larger presence of women at the 
workplace puts greater pressure towards the provision of services to conciliate employment and family duties ${ }^{3}$.

In accordance with the hypothesis 3 the firms' propensity to welfare provision is increased by the presence of union representatives in the firm. On the one hand, the employer may be willing to grant welfare benefits as this makes it easier to reach an agreement and establish more cooperative relations with the unions (Davis and Kalleberg, 2006). On the other hand, the union may especially favour the welfare provision if the firm is hit by an ageing process and, in particular, after a sudden increase of the retirement requirements. Barnes et al. (2009) show that the presence of a union is positively associated with the adoption of strategies for the ageing management by the employer.

From the full model estimates shown in column [3], the firm's size turns out to be the most influential variable. Notably, firms with more than 249 employees have the coefficient with the largest magnitude and are statistically significant, showing that they are much more likely to provide welfare services than smaller ones. The higher propensity of large companies toward private welfare is not surprising (Ferrera and Maino, 2014). Indeed, small businesses most of the time lack the financial and organizational resources required to establish a welfare plan, or it may be more costly for them. On the contrary, larger firms are able to exploit scale economies and market power in purchasing and delivering the benefits (Fleischmann et al. 2015). Moreover, large firms, which usually adopt formalized management practices, are more inclined to use welfare provision as an instrument of human resources policy. The family firms, instead, show little interest in providing welfare services. When a firm is owned by a family, and it is likely run by family members, the managerial style is usually less prone to setting up a welfare plan.

The results also prove hypothesis 2.3 predicting that if a firm is engaged in innovative activities it is also more likely that it offers some benefits to its employees. Since innovation requires the active involvement of workers, employers are willing to motivate and compensate them also through welfare schemes.

Finally, estimates show that the better the performance realized the higher is the probability that firms provide welfare benefits as revealed by the positive and statistically significant coefficient of the value of sales.

Turning to the Probit model, whose results are reported in columns [4]-[6] of Table 4, estimates of the average marginal effect (AME) are pretty close in magnitude and statistically significant to the OLS coefficient estimates just discussed. Most importantly, renouncing the hiring plan because of the pension reform predicts an increase in the probability of providing social services that range between $5.4 \%$ to $2.2 \%$ according to the specification considered in our equation (1). This is a further confirmation of our main hypothesis. In addition, Probit estimates confirm that the provision of social services is more likely if the firms are large and innovative, with the presence of union representatives and an employment composition characterized by highly educated and trained workers.

\footnotetext{
${ }^{3}$ As an example Barnes et al. (2009) report that in the UK firms where the incidence of female labour is higher are more likely to adopt strategies to cope with the ageing of the workforce.
} 
Table 4:- Regression results: Ols and Probit estimates

\begin{tabular}{|c|c|c|c|c|c|c|}
\hline & \multicolumn{3}{|c|}{ Ols } & \multicolumn{3}{|c|}{ Probit } \\
\hline & [1] & [2] & [3] & [4] & [5] & [6] \\
\hline Pens & $\begin{array}{c}0.070^{* * *} \\
{[0.010]}\end{array}$ & $\begin{array}{c}0.050 * * * \\
{[0.010]}\end{array}$ & $\begin{array}{c}0.029 * * * \\
{[0.010]}\end{array}$ & $\begin{array}{c}0.054^{* * *} \\
{[0.006]}\end{array}$ & $\begin{array}{c}0.038 * * * \\
{[0.006]}\end{array}$ & $\begin{array}{c}0.022^{* * *} \\
{[0.007]}\end{array}$ \\
\hline \multicolumn{7}{|l|}{ Workforce characteristics } \\
\hline$\%$ aged $>49$ & & $\begin{array}{c}0,003 \\
{[0.011]}\end{array}$ & $\begin{array}{c}0,011 \\
{[0.012]}\end{array}$ & & $\begin{array}{c}0,003 \\
{[0.012]}\end{array}$ & $\begin{array}{c}0,01 \\
{[0.014]}\end{array}$ \\
\hline$\% 34<$ aged $<50$ & & $\begin{array}{c}-0,005 \\
{[0.010]}\end{array}$ & $\begin{array}{c}-0,001 \\
{[0.011]}\end{array}$ & & $\begin{array}{c}-0,004 \\
{[0.011]}\end{array}$ & $\begin{array}{c}-0,004 \\
{[0.013]}\end{array}$ \\
\hline$\%$ graduated & & $\begin{array}{c}0.045 * * * \\
{[0.015]}\end{array}$ & $\begin{array}{c}0.041^{* *} \\
{[0.019]}\end{array}$ & & $\begin{array}{c}0.033 * * * \\
{[0.012]}\end{array}$ & $\begin{array}{l}0.026^{*} \\
{[0.016]}\end{array}$ \\
\hline$\%$ upper secondary & & $\begin{array}{c}0,003 \\
{[0.007]}\end{array}$ & $\begin{array}{c}-0,004 \\
{[0.008]}\end{array}$ & & $\begin{array}{c}0,003 \\
{[0.009]}\end{array}$ & $\begin{array}{c}-0,003 \\
{[0.011]}\end{array}$ \\
\hline$\%$ trained & & $\begin{array}{c}0.042 * * * \\
{[0.005]}\end{array}$ & $\begin{array}{c}0.031 * * * \\
{[0.005]}\end{array}$ & & $\begin{array}{c}0.041 * * * \\
{[0.005]}\end{array}$ & $\begin{array}{c}0.031 * * * \\
{[0.005]}\end{array}$ \\
\hline$\%$ temporary contracts & & $\begin{array}{c}-0.002 \\
{[0.009]}\end{array}$ & $\begin{array}{c}-0.008 \\
{[0.011]}\end{array}$ & & $\begin{array}{c}-0.008 \\
{[0.013]}\end{array}$ & $\begin{array}{c}-0.007 \\
{[0.016]}\end{array}$ \\
\hline$\%$ female & & $\begin{array}{c}0,009 \\
{[0.007]}\end{array}$ & $\begin{array}{l}0.018^{*} \\
{[0.010]}\end{array}$ & & $\begin{array}{c}0,005 \\
{[0.008]}\end{array}$ & $\begin{array}{c}0,017 \\
{[0.011]}\end{array}$ \\
\hline Union & & $\begin{array}{c}0.051 * * * \\
{[0.005]}\end{array}$ & $\begin{array}{c}0.016 * * * \\
{[0.005]}\end{array}$ & & $\begin{array}{c}0.047 * * * \\
{[0.004]}\end{array}$ & $\begin{array}{c}0.014 * * * \\
{[0.005]}\end{array}$ \\
\hline Firms characteristics & & & & & & \\
\hline Family firm & & & $\begin{array}{c}-0.014^{* *} \\
{[0.006]}\end{array}$ & & & $\begin{array}{c}-0.010^{*} \\
{[0.005]}\end{array}$ \\
\hline In (sales) & & & $\begin{array}{c}0.010 * * * \\
{[0.002]}\end{array}$ & & & $\begin{array}{c}0.008 * * * \\
{[0.002]}\end{array}$ \\
\hline Product innovation & & & $\begin{array}{c}0.012 * * \\
{[0.006]}\end{array}$ & & & $\begin{array}{c}0.013^{* *} \\
{[0.005]}\end{array}$ \\
\hline Process innovation & & & $\begin{array}{c}0.024 * * * \\
{[0.006]}\end{array}$ & & & $\begin{array}{c}0.024 * * * \\
{[0.005]}\end{array}$ \\
\hline $49<$ n of employee $<250$ & & & $\begin{array}{c}-0,004 \\
{[0.006]}\end{array}$ & & & $\begin{array}{c}0,001 \\
{[0.006]}\end{array}$ \\
\hline N of employee $>249$ & & & $\begin{array}{c}0.128 * * * \\
{[0.015]}\end{array}$ & & & $\begin{array}{c}0.053 * * * \\
{[0.009]}\end{array}$ \\
\hline Other controls & no & no & yes & no & no & yes \\
\hline Constant & $\begin{array}{c}0.060 * * * \\
{[0.002]}\end{array}$ & $\begin{array}{c}-0.016^{* *} \\
{[0.008]}\end{array}$ & $\begin{array}{c}-0.176 * * * \\
{[0.028]}\end{array}$ & & & \\
\hline $\mathrm{R} 2$ & 0,006 & 0,064 & 0,105 & & & \\
\hline Obs & 14600 & 14600 & 12378 & 14600 & 14600 & 12378 \\
\hline
\end{tabular}

Note: other controls include: employers' demographic characteristics, employment professional composition (executives, blue collar, white collar), sector of activity, macro-region. Robust standard errors in parentheses; ${ }^{* * *} p<0.01, * * p<0.05, * p<0.1$.

Source: EES 2015

In essence, the estimates associated to our key variable (Pensi), even when different regression models and specifications are considered, always confirm our main hypothesis, suggesting that FW schemes may represent a way to manage workforce ageing. More in general, these results are a first step toward a better understanding of the mechanism that links pension reforms to the strategic approach to workforce ageing and the diffusion of firm-level private welfare 


\section{ROBUSTNESS}

As mentioned before, firms that renounced hiring plans due to the introduction of the Law 214/2011 may be statistically different to those that did not change their hiring policies over the period 20122014, even though the policy shock was exogenous and unanticipated. Hence, we test the robustness of the relationship between Pens $_{i}$ and $W e l f_{i}$ by performing propensity score matching (PSM) methods which enable us to control for sample selection by adjusting for pre-treatment (pre-reform) observable variables. In particular, the PSM methods require to combine a group of "treated" firms that changed hiring plans due to an unexpected increase in the retirement age, with a group of "untreated" firms having similar observable characteristics which were not changed after the reform. This control group is then used to estimate the unobservable (counterfactual) probability to provide welfare services.

The variables used for matching the two samples are the same included in our more complete specification of equation (1). In order to adjust for pre-treatment (pre-reform) observable differences between the treated and untreated firms (Abadie and Imbens, 2006), the matching procedure is run on the longitudinal component of EES data that allows to collect information on firms operating both in 2010 and 2014 sample years. For comparative purposes, the PSM methods are also performed on cross sectional data, as done until now ${ }^{4}$.

To assess the quality of the matching, Tables A2 and A3 (see Appendix) present the differences between the mean value of a subset of the variables (sectoral dummies are not reported to save space) which are used to match the treatment and control groups. Overall the figures in Tables A2 and A3 confirm that the two groups, though initially different, appear to be rather similar after the matching, with no statistical differences in the means of the reported values and only two significant ones among the 30 background variables used in PSM. In other words, the matching is successful even though matching on some variables (namely family ownership, etc.) falls below conventional significant values. Finally, after imposing the common support condition, Table 5 displays the Average Treatment Effect (ATE) and the Average Treatment Effect on Treated (ATET) estimates obtained using the nearest neighbour matching procedure ${ }^{5}$.

As shown, columns (1) and (2) of Table 5 indicate that the ATE and ATET estimates found for the cross sectional samples are very similar to those presented in Table 4, confirming that giving up the hiring plans after the reform caused a rise of about $3 \%$ in the probability of employer-provided welfare. Furthermore, the ATE and ATET estimates in columns (1) and (2) are very similar in magnitude and statistical significance, suggesting that the effect of the pension reform does not differ markedly between treated and untreated firms, i.e., no sample selection on observables is at play.

\footnotetext{
${ }^{4}$ We also estimate the exogenous factors that are expected to affect the probability of changing hiring plans over the period 20132014 , i.e., of being "treated", in technical jargon. The results are available upon request.

${ }^{5}$ We use the nearest neighbour matching procedure which is available in the teffects Stata 14 command, because it computes more accurate standard errors than those computed by bootstrapping in other popular PSM estimation commands, as in the case of psmath2 (see Abadie and Imbens, 2016). After imposing the common support condition in the pre-period reform (2010), we report two estimates of interest that are provided by this command: the average treatment effect (ATE) and the average treatment effect on the treated (ATET). However results derived with other PSM procedure (commands area available upon request).
} 
On the other hand, columns (3) and (4) reveal that the ATE estimate $(+8.3 \%)$ is substantially lower in magnitude than the ATET estimate $(+10.5 \%)$, suggesting that Pens $s_{i}$ has a causal effect on our dependent variable, which would be somewhat higher in treated firms (i.e. those more likely to renounce new hires) with respect to the entire population. Then ATE and ATET estimates reported in columns (3) and (4) reveal that if we adjust properly for the observable differences in the pre-reform period (2010) between treated and untreated firms, the unexpected increase of the mandatory age for retirement unambiguously causes a rise in the propensity to provide welfare benefits mainly in the subgroup of the treated ones. This result is very important. When the treatment and the control groups become homogeneous in terms of observables, the impact of Pens on Welf is [similar] to the simple OLS and probit estimates of Table 4.

Table 5 - propensity-score matching estimates

\begin{tabular}{lccc|cc}
\hline & \multicolumn{2}{c|}{ Cross section 2010 } & \multicolumn{2}{c}{ Panel 2010-2014 } \\
\cline { 2 - 5 } & ATE & ATET & ATE & ATET \\
\hline \multirow{3}{*}{ Pens } & $(1)$ & $(2)$ & $(3)$ & $(4)$ & $0.105^{* * *}$ \\
N of Obs & $0.027^{* *}$ & $0.029^{* *}$ & $0.083^{* *}$ & {$[0.024]$} & 2757 \\
\hline
\end{tabular}

Note: ATE and ATT-PSM estimates including all the covariates in the most extensive specification as controls. We impose the common support condition using the teffects stata command which implements nearest neighbour matching on the estimated propensity score. The standard errors implemented in teffects psmatch are those derived by Abadie and Imbens(2012). Pretreatment control variables: employers' demographic characteristics, employment composition (gender, contractual arrangement, etc.), firms' characteristics (sector of activity, size, macro-region, etc.). Robust standard errors in parentheses; ${ }^{* * *} p<0.01, * *$ $p<0.05, * p<0$.

Source: EES 2015.

Then we may conclude that the results presented in this section are consistent with our basic hypothesis. Firms affected by an exogenous and unexpected increase in the retirement age are significantly more likely to introduce private welfare in favour of their employees than those that were not affected, even controlling for a wide array of workforce and firm characteristics as well as for the nature of industrial relations. 


\section{CONCLUSIONS}

This study is based on the hypothesis that pension reforms may have relevant effects on the labour demand side and, especially, on firms' strategies. In this regard it adds substantially to the existing literature as it investigates whether the voluntary provision of welfare benefits does represent a strategy which employers may choose to cope with the effects of an ageing workforce.

In particular, we exploit information derived from ESS to define firm-provided welfare (FW) schemes as benefits that the firm provides on a voluntary basis to the employees, following a unilateral decision or an agreement with unions, and whose cost are at least partially borne by the firm. These include many services and non-monetary benefits related to health, education and training, complementary pensions, leisure activities, etc. Such benefits add to the employee's remuneration and may also have an impact on the productivity and the competitiveness of the company. In addition, FW represents an essential way to attract valuable human capital and encourage retention of valid resources.

Despite the increasing diffusion of FW schemes, empirical analyses on them are still rare. In particular, there is a lack of knowledge on the workforce characteristics of firms providing them.

The analysis developed by this study takes advantage of a large and representative sample of Italian firms which were potentially exposed to the impact of the unexpected major pension reform that occurred in Italy in 2011. The main hypothesis considered is that, beyond the immediate freeze of hirings, those firms hit by the effect of the reform were more likely to adopt a welfare scheme in favour of their employees. The welfare provision, in our opinion, represents a possible strategy to manage an ageing workforce since it may contribute to sustain older workers' productivity as well as their wellbeing.

Our data show that $4,3 \%$ of the whole sample and $24 \%$ of the larger firms offered some benefits or services. As for their content, these provisions concern a wide variety of fields, from healthcare to childcare, from private pension plans to family allowances. It is worth noticing that the incidence of FW is higher in public utilities and in finance. In these industries, which are more protected from competition, FW may represent a tool to redistribute monopolistic rents to the employees. On the contrary, in industries more exposed to competition, like manufacturing, the provision of benefits by the employer are more likely to be directed also to increasing productivity by attracting, motivating and retaining employees, including the older ones.

The econometric estimates through OLS and probit models point out a strong association between the pension reform and the provision of welfare benefits. In addition to that, by a propensity score matching approach we run a counterfactual analysis which proves that the sudden increase of the retirement age brought about by the pension reform has increased the likelihood of FW schemes.

According to our results the employer's propensity towards FW schemes increases with the firm's size, the percentage of workers holding a tertiary degree, the share of trained workers and with the presence of unions' representatives. On the contrary neither the age nor the gender composition of the workforce seems to exert a relevant effect. Finally, our results show that those firms engaged in some kind innovation are also more involved in welfare programs. 
Lastly, as the postponement of age retirement has become a primary goal of economic policy in advanced and ageing societies, the firms have to cope with a structural increase in the share of old employees. The voluntary provision of welfare benefits and services can represent a strategy to maintain the wellbeing of the older workers as well as to sustain their productivity. 


\section{APPENDIX A}

Table A - Variables definition

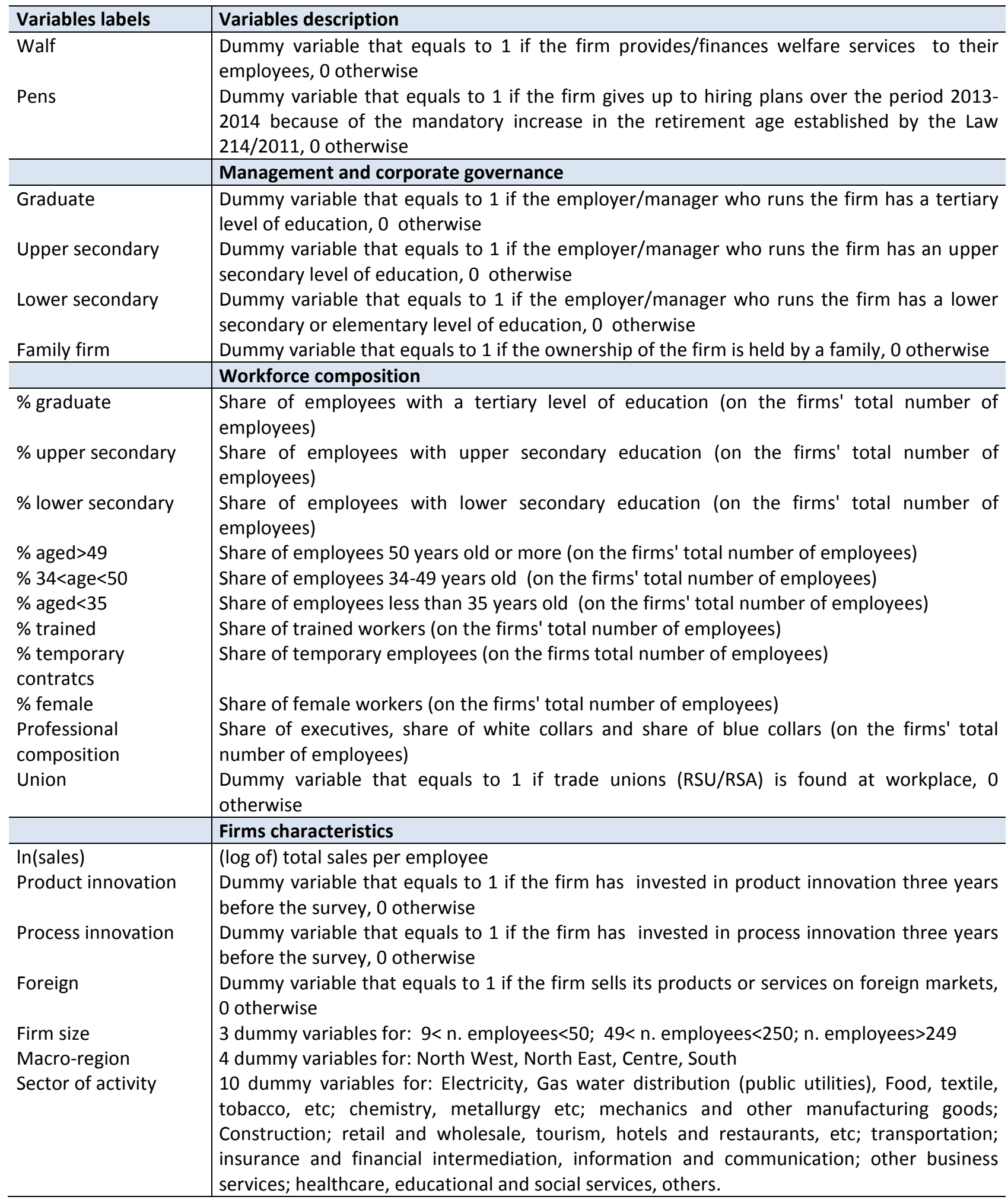

Source: EES 2015 
Table A1 - Descriptive statistics for EES population

\begin{tabular}{lcccc}
\hline & $\begin{array}{c}\text { Total number of } \\
\text { employees }\end{array}$ & $\begin{array}{c}\text { Average number } \\
\text { of employees }\end{array}$ & $\begin{array}{c}\text { Total number of } \\
\text { firms }\end{array}$ & $\begin{array}{c}\text { Average incidence of } \\
\text { firms }\end{array}$ \\
\hline Welfare services & 1438577 & 0.191 & 7422.223 & 0.043 \\
Maternity leaves and child care & 585357 & 0.078 & 1414.849 & 0.008 \\
Health care & 467543.3 & 0.062 & 1993.328 & 0.012 \\
Current family expenditure & 72831.35 & 0.010 & 348.5019 & 0.002 \\
Private pension plans & 147686.3 & 0.020 & 978.9032 & 0.006 \\
Other (findge benefits, ecc) & 165159.5 & 0.022 & 2686.641 & 0.016 \\
No welfare services & 6099844 & 0.809 & 163772.5 & 0.957 \\
Total & $\mathbf{7 5 3 8 4 2 2}$ & & $\mathbf{1 7 1 1 9 4 . 7}$ & \\
\hline
\end{tabular}

Source: EES data 2011. Note: all statistics refer to the subsample of the EES sample with more than 9 employees

Table A2 - Quality of the matching procedure. Balance property for 2014

\begin{tabular}{|c|c|c|c|c|c|c|}
\hline \multirow[t]{2}{*}{ Variable } & \multicolumn{2}{|c|}{ Mean } & \multirow[b]{2}{*}{ \%bias } & \multicolumn{2}{|c|}{ T-test } & \multirow[t]{2}{*}{$\mathrm{V}(\mathrm{T}) / \mathrm{V}(\mathrm{C})$} \\
\hline & Treated & Control & & $\mathbf{T}$ & $p>t$ & \\
\hline Aged $>49$ & 0.297 & 0.293 & 2.6 & 0.61 & 0.544 & 0.91 \\
\hline $34<$ aged $<50$ & 0.482 & 0.488 & -3.4 & -0.86 & 0.391 & 0.93 \\
\hline Graduated & 0.113 & 0.109 & 2.5 & 0.66 & 0.512 & 0.93 \\
\hline Upper secondary & 0.446 & 0.448 & -0.9 & -0.21 & 0.833 & 1.01 \\
\hline Executive & 0.052 & 0.055 & -2.6 & -0.57 & 0.568 & $0.80^{*}$ \\
\hline White collar & 0.341 & 0.342 & -0.3 & -0.09 & 0.931 & 0.98 \\
\hline Trained & 0.484 & 0.506 & -5.6 & -1.31 & 0.189 & 0.97 \\
\hline Fixed term contract & 0.067 & 0.067 & 0 & 0.01 & 0.994 & 1.06 \\
\hline Female & 0.292 & 0.293 & -0.2 & -0.04 & 0.97 & 1.07 \\
\hline Union & 0.601 & 0.589 & 2.5 & 0.57 & 0.566 & . \\
\hline Graduated man & 0.451 & 0.434 & 3.5 & 0.79 & 0.432 & . \\
\hline Upper secondary man & 0.423 & 0.437 & -2.8 & -0.66 & 0.511 & . \\
\hline Family firm & 0.664 & 0.678 & -2.9 & -0.65 & 0.518 & . \\
\hline In (sales) & 16.234 & 16.268 & -1.9 & -0.43 & 0.667 & 1.07 \\
\hline Product innovation & 0.588 & 0.609 & -4.2 & -0.97 & 0.33 & . \\
\hline Process innovation & 0.533 & 0.523 & 2.1 & 0.48 & 0.633 & . \\
\hline North Ovest & 0.346 & 0.337 & 1.8 & 0.41 & 0.681 & . \\
\hline North East & 0.308 & 0.336 & -6 & -1.35 & 0.178 & . \\
\hline Centre & 0.174 & 0.164 & 2.6 & 0.64 & 0.524 & . \\
\hline South & 0.172 & 0.163 & 2.1 & 0.52 & 0.601 & . \\
\hline $9<\mathrm{n}$ of employee $<50$ & 0.419 & 0.444 & -5 & -1.14 & 0.255 & . \\
\hline $49<$ n of employee $<250$ & 0.419 & 0.394 & 5.4 & 1.19 & 0.233 & . \\
\hline $\begin{array}{l}\text { N of employee }>249 \\
\text { Sector* }\end{array}$ & 0.161 & 0.162 & -0.3 & -0.06 & 0.953 & . \\
\hline
\end{tabular}

Note: calculations performed with the teffects module in Stata14. Statistics for the remained controls considered in the descriptive and econometric analysis (section 4) have been omitted for brevity but are available upon request 
Table A3 - Quality of the matching procedure. Balance property for 2010-2014

\begin{tabular}{|c|c|c|c|c|c|c|}
\hline \multirow[t]{2}{*}{ Variable } & \multicolumn{2}{|c|}{ Mean } & \multirow[b]{2}{*}{ \%bias } & \multicolumn{2}{|c|}{ T-test } & \multirow[t]{2}{*}{$\mathrm{V}(\mathrm{T}) / \mathrm{V}(\mathrm{C})$} \\
\hline & Treated & Control & & $t$ & $p>t$ & \\
\hline Aged $>49$ & 0.243 & 0.246 & -2.1 & -0.25 & 0.801 & 0.84 \\
\hline $34<$ aged $<50$ & 0.514 & 0.503 & 6.7 & 0.89 & 0.373 & 0.81 \\
\hline Graduated & 0.091 & 0.092 & -0.3 & -0.05 & 0.961 & 0.89 \\
\hline Upper secondary & 0.375 & 0.370 & 2.3 & 0.31 & 0.755 & 0.95 \\
\hline Executive & 0.050 & 0.053 & -3.5 & -0.46 & 0.648 & 0.8 \\
\hline White collar & 0.323 & 0.307 & 6 & 0.83 & 0.406 & 0.97 \\
\hline Fixed term contract & 0.066 & 0.069 & -2.3 & -0.38 & 0.705 & $0.66^{*}$ \\
\hline Female & 0.321 & 0.324 & -1.2 & -0.16 & 0.873 & 1.03 \\
\hline Trained & 0.330 & 0.337 & -1.9 & -0.25 & 0.805 & 0.93 \\
\hline Union & 0.630 & 0.630 & 0.0 & 0.00 & 1.00 & . \\
\hline Graduated man & 0.460 & 0.466 & -1.3 & -0.16 & 0.875 & . \\
\hline Upper secondary man & 0.404 & 0.383 & 4.4 & 0.56 & 0.574 & . \\
\hline Family firm & 0.676 & 0.642 & 7.4 & 0.91 & 0.363 & . \\
\hline Product innovation & 0.586 & 0.586 & 0.0 & 0.00 & 1.000 & . \\
\hline Process innovation & 0.543 & 0.559 & -3.1 & -0.39 & 0.693 & . \\
\hline In (sales) & 16.220 & 16.256 & -2 & -0.26 & 0.798 & 1.13 \\
\hline North Ovest & 0.410 & 0.380 & 6.4 & 0.80 & 0.422 & . \\
\hline North East & 0.306 & 0.318 & -2.7 & -0.34 & 0.735 & . \\
\hline centre & 0.136 & 0.142 & -1.7 & -0.23 & 0.821 & . \\
\hline South & 0.148 & 0.160 & -3.3 & -0.43 & 0.664 & . \\
\hline $9<\mathrm{n}$ of employee $<50$ & 0.417 & 0.380 & 7.6 & 0.96 & 0.336 & . \\
\hline $49<$ n of employee $<250$ & 0.395 & 0.448 & -11.1 & -1.35 & 0.177 & . \\
\hline N of employee $>249$ & 0.188 & 0.173 & 4.5 & 0.51 & 0.61 & . \\
\hline Sector* & & & & & & \\
\hline
\end{tabular}

Note: calculations performed with the teffects module in Stata14. Statistics for the remained controls considered in the descriptive and econometric analysis (section 4) have been omitted for brevity but are available upon request. 


\section{REFERENCES}

ABADIE, A., Imbens G. (2008), On the Failure of the Bootstrap for Matching Estimators, Econometrica, Vol. 76, pp. 1537--1557

AbAdIE, A.,. Imbens G. (2012), Matching on the Estimated Propensity Score,. Econometrica, Vol 84 (2), pp. 781-807

AisA R., LARRAmONA G., PueYo F. (2015) Active aging, preventive health and dependency: Heterogeneous workers, differential behaviour, Journal of Economic Behavior \& Organization, 117, pp. 1-9

Ascoli U., Mirabile M.L., PAvolini E. (2012) Dal welfare di cittadinanza al welfare nel lavoro? Contrattazione collettiva e iniziativa d'impresa in Italia, Rivista delle Politiche Sociali, 3, pp. 53-76

ATKINSON C., SANDIFORD P. (2016) An exploration of older worker flexible working arrangements in smaller firms, Human Resource Management Journal, Vol 26 (1), pp. 12-28

AUBERT P., CRÉPON B. (2007) La productivité des salaries âgés: une tentative d'estimation, Economie et statistique, 368, pp. 95-119

Barnes H., Smeaton D., TAYloR R. (2009) An Ageing Workforce: The Employer's Perspective, Institute for employment studies, Brighton

Barth M., McNaught W., Rizzi P. (1993) Corporations and the Aging Workforce, in Building the Competitive Workforce: Investing in Human Capital for Corporate Success, P. H. Mirvis (ed.), John Wiley and Sons

Bassanini A., Booth A., De PaOla M., Leuven E. (2005) Workplace Training in Europe, IZA Discussion Paper No. 1640

BLoOM D.E., CANNING D., FINK G. (2010) Implications of population ageing for economic growth, Oxford Review of Economic Policy, 26 (4), pp. 583-612

Bloom D.E., SouSA-PozA A. (2013) Aging and productivity, Labour economics, 22, pp. 1-4

Boeri T., Garibaldi P., Moen E. (2016) A clash of generations? Increase in Retirement Age and Labor Demand for Youth, WorkInps paper 1

Bovini G., PARADISI M. (2017) The Transitional Labor Market Consequences of a Pension Reform, mimeo

Clark R.L., Sandler Morrill M. (2017) Working Longer, Retiring Later: Are Employers Ready for the New Employment Trend?, Employment Research 24(2), pp. 4-6

D'Addio A.C., KeESE M., Whitehouse E. (2010) Population ageing and labour markets, Oxford Review of Economic Policy, 26 (4), pp. 613-635

DAVIS AND Kalleberg (2006) Family-Friendly Organizations? Work and Family Programs in the 1990s, Work and Occupations, 33 (2), pp. 191-223

DOSTIE B. (2006) Wages, productivity and aging, IZA discussion paper 2496

EUROPEAN COMMISSION (2012) Employment and Social Developments in Europe 2011, Luxembourg.

Fehr E., Goette L., Zehnder C. (2009) A Behavioral Account of the Labor Market: The Role of Fairness Concerns, Annual review of economics, 1, pp. 355-384 
FERrERA M., MAINo F. (2014) Social innovation beyond the state. Italy's Second Welfare in a European Perspective, Centro Einaudi, w.p. 2

FleISCHMANN M., KOSTER F., SCHIPPERS J. (2015) Nothing ventured, nothing gained! How and under which conditions employers provide employability-enhancing practices to their older workers, The International Journal of Human Resource Management, 26:22, pp. 2908-2925

GÖBEL C., ZWICK T. (2013) Are personnel measures effective in increasing productivity of old workers?, Labor Economics, 22, pp. 80-93

GRUND C., WeSteRgaRd-NieLSEN N. (2008) Age structure of the workforce and firm performance, International journal of manpower, 29 (5), pp. 410-422

Hellerstein J.K., Neumark D. (2004) Production function and wage equation estimation with heterogeneous labor: evidence from a new matched employer-employee data set, NBER Working Paper Series, 13, pp. 345-371

HowITT P. (2002) Looking inside the labor market, Journal of economic literature, 40(1), pp. 125-138 ILMAKUNNAS P., MALIRANTA M. (2007) Aging, labor turnover and firm performance, Discussion Paper 1092, The Research Institute of the Finnish Economy

KUBE S., MARÉCHAL M.A., PUPPE C. (2012) The currency of reciprocity: gift-exchange in the workplace, American economic review, 102(4), pp. 1644-1662

KUBe S., MARÉCHAL M.A., PUPPE C. (2013) Do wage cuts damage work morale? Evidence from a natural field experiment, Journal of the European economic association, 11 (4), pp. 853-870

LALlEMAND T., RYCX F. (2009), Are young and old workers harmful for firm productivity?, De economist, 157, pp. 273-292

LAZEAR E.P. (1979) Why is there manadatory retirement?, Journal of Political Economy, 87, pp. 1261 -64 LaZEAR E.P. (1990) Adjusting to an Aging Labor Force, in D.A. Wise (ed.) Issues in the Economics of Aging, University of Chicago Press

MARTINS P.S., Novo A.A., PORTUgAL P (2009) Increasing the Legal Retirement Age: The Impact on Wages, Worker Flows and Firm Performance, IZA discussion paper 4187

Mahlberg B., Freund I., Cuaresma J.C., Prskawetz A. (2013) Ageing, productivity and wages in Austria, Labour economics, 22, pp. 5-15

NATICCHIONi P., RicCi A., RustiChelli E. (2010) Far away from a skill-biased change: falling educational wage premia in Italy, Applied Economics, 2010, vol. 42 (26), pp. 3383-3400

NiImI Y. (2017), Does Providing Informal Elderly Care Hasten Retirement? Evidence from Japan, Asian Growth Research Institute, wp 7

OthMAN S., Romle A.R., IDRIS A.M. (2015) The Impact of Employee Engagement Program In Reducing Absenteeism At Workplace: A Case Of Government-Linked Company (G/C) In Malaysia, International Journal of Administration and Governance, 1 (4), pp. 45-50

PARRY E. (2008) Managing an ageing workforce. The role of total reward, Chartered Institute of Personnel and Development, London 
Pavolini E., Ascoli U., Mirabile M.L. (2013) Tempi moderni. Il welfare nelle aziende in Italia, I I Mulino, Bologna

QuARANTA R., RicCi A. (2018) Politiche di assunzione e struttura dell'occupazione: il ruolo della riforma delle pensioni, Economia \& Lavoro, n.1, pp 173-188

SkirbeKk V. (2008), Age and Productivity Capacity: Descriptions, Causes and Policy Options, Ageing horizons, 8, pp. 4-12

TACHIBANAKI T. (2003) The role of firms in welfare provision, in Ogura S., Tachibanaki T., Wise D.A. (eds.), Labor markets and firm benefits policies in Japan and the United States, University of Chicago Press, Chicago

THE ECONOMIST (2010) The silver tsunami. Business will have to learn how to manage an ageing workforce (February $4^{\text {th }}$ )

TISHMAn F.M., VAn LoOY S., BRUYÈre S.M. (2012) Employer Strategies for Responding to an Aging Workforce, Report, NTAR Leadership center

VAN DALen H.P., Henkens K., SCHIPPeRS J. (2009) Dealing with older workers in Europe: a comparative survey of employers' attitudes and actions Journal of European Social Policy 19(1), pp. 47-60

VAn OuRS J.C., StOeldRAiJer L. (2010) Age, wage and productivity, CESifo Working Paper, No. 2965.

VANDENBERGHE V. (2013) Are firms willing to employ a greying and feminizing workforce?, Labour economics, 22, pp. 30-46

Wooldridge J. (2010) Econometric Analysis of Cross Section and Panel Data, Second Edition, The MIT Press 
ISSN 2533-2996

ISBN 978-88-543-0171-9 